Finally feasible or fresh façade? Analyzing the internationalization plans of Japanese universities

Chapple, Julian $\bowtie$

Faculty of Intercultural Communication, Ryukoku University, Japan (julian@world.ryukoku.ac.jp)

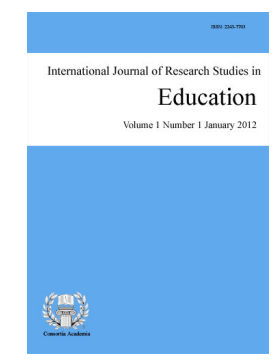

ISSN: $2243-7703$

Accepted: 23 May 2014

OPEN ACCESS

\title{
Abstract
}

Recent policy moves in Japan reflect further attempts to internationalize the nation's higher education sector. Building on previous plans, such as the goal of accepting 100,000 international students, Japan is now pinning its sights on a further increase $(300,000)$, employing more foreign faculty, sending more Japanese students abroad to study, and teaching a greater number of classes in English. Falling under the broad auspices of the 'Global 30' national project, Japan hopes its forthcoming 'Super Global Universities' plan will see it achieve the goal of 10 of its universities in the world's top 100. However, despite the slogans, the actual goals of the present plans appear decidedly domestic. The quality of higher education in Japan has long been a concern, and the nation's desire for a more globally-active and competent workforce in face of a dramatically dwindling student population base are obvious. By using a mixed method approach to examine the content of recent plans, this paper seeks to ascertain what is really being sort after and whether it can be achieved. The above-mentioned four plans reveal little in terms of policy but speak volumes about Japan's interpretation of the concept of internationalization. In particular, the widely held belief that teaching more classes in English is a remedy for the various present problems is looked at in detail. The paper concludes by examining what issues are overlooked in Japan's discussion and what they reveal about the need for societal internationalization as a pre- or co-requisite for educational internationalization.

Keywords: Japan; internationalization; higher education; English medium instruction; curriculum 


\section{Finally feasible or fresh façade? Analyzing the internationalization plans of Japanese universities}

\section{Introduction}

Higher education in Japan has a long history of influence and adaptation from abroad in order to internationalize. Recognizing the need to modernize in order to catch up with the West, Japan became the first Asian nation with modern higher educational institutions, achieved in large part from the borrowed expertise of Western specialists (Nakayama, 1989). More recently in the 1970s, having rebuilt its economy from the ruins of WW2, Japan once again began to place high value on the so-called internationalization of higher education for greater social and economic development (Iiyoshi, 2008). This time, unlike in the past, legislation was enacted to allow non-Japanese to take up fulltime, tenured faculty positions in Japan's national and public universities (Kitamura, 1987), rather than being required to return home. Next, in 1983 the Japanese government boldly announced its plan to have 100,000 international students studying in Japan in the early 20th century; a goal finally achieved in 2003 (Fujita \& Griek, 2011). Following on, in 2008, Japan initiated a subsequent policy to attract 300,000 international students and send 120,000 Japanese students abroad by the year 2020. Most recently, in 2013 the Prime Minister declared his ambitious intention to see ten Japanese universities rank among the world's top 100 over the next decade (presently there are only 2) and has earmarked 9.9 million yen in fiscal 2014 for a so-called Super Global University Project (Ministry of Finance, 2013). Clearly Japan still sees promise and necessity in higher education and many universities are desperately trying to internationalize their campuses.

However, is Japan truly serious about improving the overall quality and standing of its institutions of higher learning or merely copying global trends in search of status or students? Despite repeated policy attempts over the years aimed at internationalizing higher education, little progress has been achieved. Closely examining the most recent proposals and the reasons behind them reveals that the approach taken by Japan represents either a lack of understanding and appreciation of the difficulties involved in internationalizing tertiary education, or a willful ignorance guided by the tacit acceptance that such moves are really for showcasing Japan and not seriously seen as catalysts of change for Japanese society and its students.

\subsection{Purpose statement}

The purpose of this study was to find out what policies were predominantly being undertaken by universities in Japan in order to internationalize their campuses and assess the likelihood these would achieve the desired results. While other researchers have examined the theoretical, philosophical and macro aspects pertaining to Japan's internationalization (Hashimoto, 2000; Burgess, Gibson, Klaphake, \& Selzer, 2010), this article focuses predominantly on the micro policy content of recent proposals geared to stimulate Japanese higher education and poses the questions: can Japan's universities internationalize under the present plans and, if not, why not?

\subsection{Significance of the study}

After briefly reviewing the backdrop against which Japan's internationalization policies have emerged, the study then provides a critical assessment of the present plans, focusing in particular on the growing penchant for teaching more classes in English, a core component of internationalization strategies in Japan. Notwithstanding the considerable and growing body of literature in Europe in particular, regarding dual language education in universities, it contends that Japanese universities are more content with projecting a façade of internationalization while carefully overlooking other core issues in need of consideration. The practical implications for educators and learners - both domestic and international - of such a policy will be seen in the coming years unless more fundamental and overriding steps are taken. The paper concludes with a prescriptive 
list of practical suggestions for profound and meaningful internationalization policies for both faculty and students in Japanese higher education. Without greater attention to the complexities of providing an international experience on campus, many of the recent proposals are again likely to fail to deliver.

\subsection{Research Framework}

While a plethora of definitions exist relating to the assessment and evaluation of institutional internationalization, a number of broad overlapping criteria can be gleaned and used as a conceptual framework. Chin, Wu, \& Ching (2012) in their comparison of the degree of internationalization in the context of Taiwanese higher educational institutions use twelve indicators as measures: institutional commitments, strategic planning, funding, policy and guidelines, organizational infrastructure and resources, academic offerings and curriculum, internet presence, faculty and staff development, international students and scholars, study abroad, campus life, performance evaluation and accountability. Qiang (2003), in comparison, employs a paradigm of internationalization covering four approaches: activity (including curricula, study abroad, internationalizing faculty and recruitment of international students), competency (knowledge and skills), ethos (intercultural and international initiatives) and process (incorporating an international dimension into teaching, service and research). Knight's (2008) encompassing definition of educational internationalization claims it is the process of "integrating an international, intercultural or global dimension into the purpose, functions or delivery of higher education in the institutional and national levels" (p. 21, emphasis added). ${ }^{1}$

Seeking to analyze the overlap in the above approaches, in particular Qiang's paradigm, with those predominant in literature in Japan and evaluate their potential, this study employs a summative, mixed method approach, combining qualitative and quantitative data obtained from both interviews with university officials from 9 universities involved with internationalization and a literature review of publicly available university plans in order to obtain as broad a picture as possible of the main thrust of internationalization policies in Japan. Utilizing also the author's former position and contacts as Dean of the international office of a large Japanese university, specifically this study analyses the plans specified by the 13 universities selected by Japan's Ministry of Education, Science and Technology in its 'Global 30' project aimed at fostering "leading internationalization hubs by providing a high quality of education and an environment that makes it easy for students from other countries to study in Japan" (Japan Society for the Promotion of Science, n.d.). Formally launched in 2008, the Global 30 project set out to select 30 top-tier universities to provide funds for establishing English degree offering departments to accept more foreign teachers, international students and presumably stimulating more Japanese to study abroad. In the end, and after subsequent budget cuts, only 13 universities were selected to receive financial support.

\section{Literature Review: Internationalization or Globalization?}

In order to evaluate the proposals that Japan has made, there first needs to be an understanding of the background and climate that exists in Japan which in turn requires an appreciation of the different connotations associated with the concept of internationalization in both a Western and Japanese sense.

There is no doubt that over the past few decades, as Brandenburg and de Wit (2010, p. 31) write, "the concept of internationalization of higher education has moved from the fringe of institutional interest to the very core." Many books, articles and reports have been written, conferences and symposia organized and associations created (Stearns, 2008; Spring, 2009; Wildavsky, 2010). However, recently the concept in the West has been complicated by a further debate concerning the difference between internationalization and globalization, with some viewing them as similar points on a progressive scale (often using the latter as a synonym of the former) while others struggle to detach globalization, with its primarily negative financial connotations, from internationalization and return it to its pre-global version (linked to ideals of obtaining understanding and peace

\footnotetext{
1 Although some find even this definition to be insufficiently 'outward-looking'. See Hawawini (2011), for example, who believes internationalization is more about integrating the institution itself into a globalizing world.
} 
Chapple, J.

through educational exchange). So much has been discussed and written about this debate that it has prompted some to suggest we should "leave the old concepts of internationalization and globalization and move to a fresh unbiased paradigm" (Brandenburg \& de Wit, 2010, p. 33). Yet, at the same time, this activity itself illustrates the ongoing intellectual interest the topic generates and hence it's continued significance.

Japan has by no means been a passive spectator to this same debate as testified by the considerable volume of literature specific to the Japanese scene (Kitamura, 1987; Burgess et al., 2010; Iwabuchi, 2005; Mannari and Befu, 1985). However, the debate in Japan regarding internationalization (and its relationship with globalization) is of a different nature, reflecting a somewhat different associated purpose. In spite of its appearance, internationalization (kokusaika), in a Japanese context, has been variously used to refer to a Japanese-only nationalistic discourse; what some term a "closing in" (Burgess et al., 2010, p. 461), a "convergence to predetermined norms rather than divergence towards cultural and linguistic multiplicity" (Kubota, 2002, p. 14), or a defensive challenge to the idea of Japanese identity (Lincicome, 2005). It is, in other words, what 'we' Japanese have to do in order to deal with 'them', 'Outsiders'.

Globalization (gurobaruka), on the other hand, refers to what 'they' are doing and how we (Japanese) react to it is very much dependent on the policies 'we' implement, i.e. kokusaika. Globalization tends to be seen more as the situation 'out there' over which Japan has little control. Put differently, both kokusaika and gurobaruba describe something that surrounds Japan and requires appropriate measures; however, kokusaika, unlike gurobaruka, also describes an activity the Japanese themselves engage in (Burgess et al., 2010, pp. 464-5). This is similar to Cantwell and Malonado-Malonado's (2009) view of internationalization as the way institutions of higher education respond to globalization.

Thus, as Hashimoto (2013) explains, Japan's concept of internationalization is about promoting Japan to the international community, not about becoming part of it, which is based on a view of the world as the Japanese/Other (p. 29).

This form of internationalization also requires a view that Japan should remain a monolingual state in order to stand as a unified entity against the rest of the world. (Hashimoto, 2013, p. 29)

Paradoxically, therefore, activities undertaken in Japan in the name of internationalization can at times even be the antithesis of what is referred to as internationalization in other contexts. Keeping this background in mind, the following discussion examines the main core of recent proposals in Japan, their overt purpose, what is omitted and the implications for education.

\section{Present Proposals}

Four topics can be highlighted as the basic thrust of Japan's most recent push towards internationalization of its higher education sector, all interrelated, interdependent and, curiously, almost mirroring Qiang's (2003) activity approach. Firstly, and most recently, Prime Minister Abe outlined a plan to increase the number of foreign faculty in Japan. This move followed on from the second plan to more than double the number of international students studying in Japan. The third goal is a push to increase the number of Japanese students studying abroad and hence, the overall internationalization of society through an increase in so-called 'globally-competent personnel' (gurobaru jinzai). The final plan, aimed at making the above feasible, is to increase the number of universities offering classes or courses in English under the auspices of the aforementioned Global 30 (G30) project. What is important in Japan; a society with a very centralized education system, is the degree of adherence to the above four policies. The following discussion critiques each of the above four plans before moving on to discuss what more Japan could be doing and the possible reasons it is not.

\subsection{Increasing the number of foreign faculty}

One of the key indicators of internationalization in higher education is the degree of mobility and openness 
of an educational system to both students and faculty. As the global grab for talent intensifies, international faculty members are becoming increasingly essential for the creation of vibrant diversity on college and university campuses (Mamiseishvili \& Rosser, 2009, p. 88). As Mamiseishvili and Rosser (2009) extrapolate, today universities are investing more resources in hiring and retaining international staff given that productive faculty is the most important resource today's universities have (Gappa et al., 2007). "[A]ttracting the best—students, scholars, and research partners-from anywhere they can be found has become the modus operandi of the world's best institutions" (Salmi, 2009, p. 64). This is evidenced in the fact that international university ranking organizations such as the QS World University Ranking System, for example, include the percentage of foreign faculty as an assessment criterion, allocating maximum points to universities with faculties that are $25 \%$ (or more) international.

There are many reasons why a more international faculty contributes to the enhancement of institutions. Higher education institutions in the United States have been recruiting growing numbers of international faculty members to diversify their campuses, bring international expertise, enhance scientific innovation, and raise the awareness of the global context (e.g., Altbach, 2005, 2006; de Wit, 2002). International faculty members also bring different and unique perspectives to their classrooms, serve as role models to international students (Mamiseishvili \& Rosser, 2009), and offer alternative ideas and stimulation to their native colleagues.

As mentioned above, Japan has been quick to acknowledge the importance, outwardly at least, of a more diverse and open faculty employment system which is hardly surprising given present statistics. According to Goodman (2010), the proportion of foreign staff in Japanese universities is, by global standards, very low and in fact even decreased (in national universities) from 3.5\% in 2007 to 3.4\% in 2008 (Yonezawa, 2010, p. 132). According to Kariya (2014), as of 2011 the total number of foreign faculty teaching fulltime in Japanese universities and colleges was a mere 6,603 , or less than $4 \%$, strikingly less than the 27 percent of foreign national academics working in the United Kingdom, for example (Salmi, 2009). Prime Minister Abe recently stated that within the next three years, "eight national universities will hire 1,500 leading researchers from around the world" (quoted in Rappleye, 2013). The Prime Minister's comments were, however, unaccompanied by details about how these universities would go about this task (and with the incorporation of national universities in 2001 the government can no longer simply issue orders overriding a university's autonomy). So, while the above number makes impressive reading, it is perhaps far from realistic without concrete details, action plans or timeframes, and even if the target was reached would lead to little noticeable change since it would affect just over ten percent of the nation's universities (as of May 2013 there were 86 national universities out of a total of 770).

Japan's Ministry of Education Science, Culture, Sports, Science and Technology (MEXT) also recognize the need to increase international talent in the nation's universities. In 2005 it set up a working group tasked with looking into the 'Globalization of Universities' (daigaku no gurobaruka) and one of their final recommendations for Cabinet discussion mentioned the need to increase the number of talented (yushuna) foreign teachers, "starting with the annual salary system, universities should make efforts to implement new salary systems suited to the ability of teachers" as well as "improving the living environment for foreign teachers" (MEXT, 2013, my translation). While these statements acknowledge the reality that Japanese working practices and conditions are presently insufficient to attract talented teachers and researchers, again there is little concrete evidence suggesting changes have been made. Conditions in Japanese universities remain considerably below world class (Rappleye, 2013) and calls for improvements not backed by action plans appear to be 'displays' of internationalization unlikely to be realized without wider societal change.

\subsection{Increasing the number of foreign students in Japan}

In a similar vein to the issue of seeking a larger number of foreign faculty, and representing an even more visible 'display of internationalization,' is the plan to increase the number of international students in Japan, the core of the aforementioned G30 project. There is no doubt reaching the target of 300,000 students (the equivalent 
of approximately $10 \%$ of the entire Japanese tertiary student population) by 2020 will be challenging. However, far from being an altruistic policy aimed at fostering goodwill and understanding, it appears to be been driven in particular by the need to offset the twin problems of an inevitable decrease in the enrolment of domestic students in higher education in the coming years (Fujita \& Griek, 2011) and the ensuing associated drop in talented labor. As Maruyama (2011, p. 3) points out "[T] here was a shared understanding between the Japanese business sector and the government that Japan needed to recruit talented students to succeed in international competition." Or as a leading Japanese newspaper claims, the moves to attract foreigners are necessary as a result of the shrinking domestic market and the declining domestic population (Nikkei Shimbun, November 11, 2012, cited in Hashimoto, 2013, p. 17). With statistics revealing that approximately $45 \%$ of Japan's private four-year colleges are unable to fill their student intakes recently (Sawa, 2013), the urgency is apparent. What is more, even if the goal is obtainable, it is dubious to assume it can easily contribute to greater internationalization of the nation's institutions as many foreign students are 'segregated' into special language and culture courses (bekka) at universities, with little interaction with Japanese students.

At present, the mix of students choosing to study in Japan can hardly be called diverse. The overwhelming majority, accounting for more than $82 \%$ of all international students, come from just four nearby Asian nations, namely: China $(86,324$ or $62.7 \%)$, Korea $(16,651,12.1 \%)$, Taiwan $(4,613,3.4 \%)$ and Vietnam $(4,737,3.2 \%)$ (JASSO, 2013). This trend is unlikely to change in the immediate future. Further, Japan is competing for students in an increasingly competitive environment and, unfortunately, as the present standard of Japanese higher education is so poor many of these foreign students are actually being paid to study at Japanese universities, in the form of government scholarships (Askew, 2011). Unless the issue of quality is addressed, there is little incentive for greater numbers of talented and motivated students to choose Japan's institutions for their higher education. In order to make Japan a more attractive option, the government is focusing solely on the delivery of courses in English, it seems (examined below) without seeking to improve the quality or content of the curriculum offered.

\subsection{Sending more Japanese students overseas}

Linked to the number of students entering Japan, the issue of Japanese studying abroad has raised considerable interest in the wake of a recent marked decline in numbers. After peaking at 82,945 students studying abroad in 2004, numbers have been on a steady decline. Latest figures reveal another year-on-year drop (the sixth consecutive) of $3.1 \%$ to 58,060 in 2010 ("The number of students studying abroad falls," 2013). While clearly economic reasons are responsible for some of the decline, other factors like a lack of employment opportunities, increasing language requirements to study abroad, the younger generation's aversion to risk, and even the view that such experiences can be detrimental to career prospects, have been discussed (Lassegard, 2013; Chapple, 2013).

Universities are particularly sensitive to the issue of study abroad. Increasingly, it is being incorporated into courses and even becoming a compulsory requirement for graduation in some departments. A recent newspaper survey revealed that $94 \%$ of the 133 universities questioned foresee an increase in the number of their students studying abroad ("Universities, finding a way," 2013). Almost 28\% expected a 50\% increase on present numbers while $45 \%$ of the universities envisaged an increase of more than $30 \%$. These numbers, however, fall far short of the aforementioned University Globalization Working Group's call for doubling the number of Japanese studying abroad to 120,000 by 2020 , and again lack specific plans.

While encouraging a greater number of students to travel and study abroad naturally has the potential to expose them to priceless life-changing experiences that can equip them for future careers, it needs to be remembered that mobility alone is only a catalyst for internationalization, not a final goal. Unless undertaken as a core part of tailor-made and monitored programs with an emphasis on fostering both intercultural and linguistic skills, greater numbers of students abroad may be meaningless. Presently, with a focus on numbers alone and not the curriculum content, once again, the emphasis seems to be more cosmetic than concrete. 


\subsection{More classes in English}

Of all the proposals mentioned for internationalizing higher education in Japan today, that of offering a greater number of classes in English is gaining the most attention. Providing an opportunity to study at a university in Japan and complete a degree in English - which in turn requires more teachers capable of conducting such classes - is seen as the best way to achieve the government's numerical goal of attracting 300,000 students, and is hoped to spur more domestic students to study abroad.

To be sure, Japan is in good company. The offering of university courses in English is a growing worldwide trend. Originating both in Europe (where more than 6400 university courses are taught in English representing a massive increase over the last decade, see: ICEF Monitor, 2013) and Canada in the 1950s (Barnard, 2013), today institutions of higher education throughout the world are caught up in what Phillipson (2009) has labeled a potential 'pandemic' of teaching in English.

Following this international trend, in Japan government and big business leaders are mainly behind the push for universities to offer 10-30\% of their academic courses in English (Brady, 2008, p. 97) in a hope to be able to attract a greater number of international students (and therefore attain the goal of 300,000). However, will this really lead to an internationalization of the campus and enable Japanese students to reach greater global potential? If done properly, perhaps, but there are numerous pitfalls and issues that appear to have been conveniently overlooked in the rush forward.

Firstly, there is considerable doubt as to whether the offering of courses, or the opportunity to graduate in English for that matter, will necessarily lead to greater intercultural experiences for both the international students and the host nation. As Cason and Rodriguez (2013, p. 15) write:

For non-native speaking students, there may be good reasons for them to study in English, but having native English speakers studying abroad in their own language does not necessarily engage them well with their host cultures.

Engagement comes when universities carefully provide the correct tools and environment so as to avoid the creation of what Cason and Rodriguez (2013) refer to as an "Erasmus bubble" (the phenomena of European students in the European Community Action Scheme for the Mobility of University Students, or Erasmus program, who generally only interact with one another and not local students). In other words, universities need to ensure that international students are able to engage as much as possible with the local population and not only enjoy the company of a 'bubble group' of fellow international students. As stated above, this notion and the systems required to enable it, are as yet rare in Japan.

Secondly, in order to be successful, the method of delivery of courses in another language needs to be carefully undertaken. Of the various approaches available for teaching content in English, the Content and Language Integrated Learning (CLIL) approach is the most developed (Symon \& Weinberg, 2013). This dual-focused approach would see English used for the teaching and learning of both content and language (Marsh et al., n.d.). While it has been well tested and implemented in primary and secondary levels, tertiary teachers are probably less well versed. In Japan, in particular, where teaching content in a language other than Japanese is still a rare and novel phenomenon at any educational level, the pedagogy relevant to teaching in English is sparse. Consequently, the approach still often tends to be English Medium Instruction (EMI) where emphasis is on content acquisition and any language development is seen more as a bonus (Symon \& Weinberg, 2013). While this approach clearly offers benefits for international students on Japan's campuses by ensuring a certain academic level is obtained, it is not conducive to assisting Japanese students with their goal of language advancement. Further without the use of techniques such as scaffolding or sheltered content instruction to assist and support (Echevarria \& Graves, 2006; Gibbons, 2002; Mohan, 2001), often students fail to comprehend the content and drop out (Selzer \& Gibson, 2009) leading to the creation of those Erasmus bubbles. 
Thus, unless carefully prepared, monitored and followed up, an EMI approach alone is unlikely to either benefit Japanese students much or contribute to the development of their international outlook. Preparation must involve examining not only the method of delivery or whether language assistance is offered (and how much) but also extend to such things as the extent of language use (in class only, using native language for tests and assignments), how much to teach, evaluation criteria and so forth. Perhaps, for example, the adoption of a dual-medium model "in which the output texts could be written in English, and appropriately organised, with summaries/and abstracts written in the first language" (Barnard, 2013, p. 12) would be more applicable. But, as Symon and Weinberg (2013, p. 24) fear:

\section{inadequately prepared EMI instructors may believe they only need translate their course from one language to the other in order to teach effectively in English and that no other modifications or adaptions are necessary.}

Recent trends and public opinion in Japan seem to follow the notion that merely translating classes into, or offering the same content in English, is sufficient. Kyoto University, for example, is planning on hiring 100 new foreign teachers over the next 5 years to teach half of its undergraduate general liberal arts classes in English ("Two barriers to internationalization," 2013). However, this approach fails to address whether the original Japanese content was up to standard in the first place. Symon and Weinberg (2013) conclude that appropriate infrastructure such as writing centers and self-access language centers along with support systems for students and lecturers are essential requirements before any EMI courses can be successful. And, as Barnard (2013, pp. 12-13) claims, above all "it is necessary to sensitise all stakeholders to the importance of bilingual academic literacy and to the necessary shift in role perceptions". Yet, there is scant recognition of such requirements in Japan.

A third issue that needs to be addressed is the question of who will teach. Presently, the method of teaching in English at the tertiary level in Japan leaves a lot to be desired in terms of both quality and technique. Smith points out that there are two components in the link between internationalization and quality of education: delivery and "the question of how the international dimension of higher education can actually enhance the quality" (Smith, 1994, p. 17). In many cases classes are either taught by those who are able or willing and not necessarily those best qualified in a subject. However, "the ability to read widely and write at length in a second language does not necessarily transfer to effectively explaining key concepts to students in such a way as to make the lectures comprehensible" (Barnard, 2013, p. 4). An insufficient focus on the quality of the language of instruction naturally leads to a decline in the overall quality of education (de Wit, 2011). Further complicating the issue is the fact that Japanese students tend to have a negative impression of the English ability of Japanese teachers and generally view English spoken by Japanese and other Asians negatively (Shimizu, 2000; McKenzie, 2014). This is probably a result of a lack of understanding of communication norms and a traditional educational bent towards the belief that native speakers are the only real speakers. Deconstructing this belief is an important prerequisite to not only breaking down stereotypes to allow for meaningful teaching to take place, but also in the wider scheme of things, fostering Japanese students capable of interacting with greater ease globally.

A fourth question that needs to be asked is related to the choice of the median of instruction itself: English. In Europe, where programs such as ERASMUS enable student mobility throughout the region, the growing trend is towards using English as the lingua franca for instruction. Such a decision, however, was neither made in haste nor reached without considerable debate and upset. Ongoing today is the reluctance in many European nations to board the 'English bus,' and heated opposition is not uncommon, as states fear a loss of cultural and linguistic identity (Vihman, 2013; Brock-Utne, 2013). However, Japan is today actively promoting English education in English policies from secondary school upwards, with plans for a future lowering still. ${ }^{2}$ To an outside casual observer this has the appearance of embracing internationalization openly. But, appearances are deceiving. While there is little debate today that English is the "uncontested lingua franca for science, technology, politics,

\footnotetext{
2 Since 2013, high schools are expected to teach English classes in English, a trend which is planned to be extended to junior highs in the near future. (See Holifena, n.d.).
} 
commerce and popular culture" (Symon \& Weinberg, 2013, p. 22), is it really the best choice for all disciplines in all universities in Japan? Will English alone allow Japan's graduates to reach their full potential? Can we consider universities to be 'international' when only one foreign language is promoted? Is a monolingual foreign language policy beneficial to Japan and its future? Will it not lead merely to the development of an elite class of bilingual speakers? These questions remain unanswered and there is widespread adherence in Japan to the flawed belief that education offered in English is the equivalent of internationalization (de Wit, 2011).

A related point to note is that, as mentioned above, presently the majority of Japan's international students are from Asia. These students are not necessarily interested in, nor always capable of, enrolling in classes taught in English. In fact, their Chinese character linguistic background was in many cases the driving factor for their choosing Japan as a destination. Undoubtedly Japan's leaders hope that by providing more chances to study in English they will be able to tap into a much larger and more diverse student population pool. Consequently, it appears that the push to teach more classes in English is another 'display' of internationalization more than a policy carefully built on detailed research.

Finally, we must also consider how prudent it is to 'suddenly' start teaching courses in English at university for Japanese students when many have had little or no prior experience with, or exposure to, classes taught in any language other than Japanese. Thus, the discussion here resonates well with Hashimoto's (2013) seemingly oxymoronic comment that internationalization in Japan actually requires Japan to remain monolingual in order to stand unified against the rest of the world. In present form, proposed plans will ensure bilingualism is still out of reach for the majority of Japanese university students and could lead to the creation of an elite English class, making us question the integrity of such plans.

\section{Discussion: Feasible, Flawed, or Façade? What's missing?}

In spite of the recent plans outlined here, the evidence suggests Japan remains intent to keep things as they are in many ways. We also need to remember that universities in Japan, in many cases, serve a slightly different purpose, to their international counterparts (Igami, 2014), often acting as a kind of human-resource filter. Worthman $(2013$, p. 27), in his explanation of a hybrid course he created to assist teachers in a Mexican university to teach in English, points out how faculty need to identify the effects of globalization in their contexts, so they can delve into that which they were familiar, "but often forgot in a policy reaction to globalization, such as local knowledge, culture, languages, needs and globalization's effect on these needs." This complex, yet essential process, which Worthman (2013) refers to as "academic calisthenics," is precisely what faculty and administrators at Japanese universities need to address. By continually questioning how the pressures of globalization can be dealt with in a Japanese context while assisting Japanese students to become global, yet maintaining the cultural and linguistic identities that are an integral and important part of what it means to be Japanese, will lead to more meaningful classroom and overall educational experiences. Again, this requires considerable changes to not only teaching style but also teaching content.

The degree of discussion undertaken in the name of internationalization in Japan underlines the fact that internationalization is feasible and sort after, but that something is missing. The issue that is most conspicuous by its absence in the debate regarding internationalization in higher education in Japan today is curriculum, or in other words, the entire process approach outlined by Qiang (2003). It is this very lack of debate about processes and curriculum that reveals Japan's universities are more interested in cosmetic revisions rather than far-reaching changes. Further, superficial changes fail to address the fundamental and overlooked core questions about what is beneficial and for whom in curricula terms. If these, admittedly difficult, issues are tackled seriously throughout the curriculum and delivery instead of being conveniently overlooked, Japanese higher educational institutions can really begin to 'internationalize.' Put another way, until such a pedagogical approach becomes a routine part of the curriculum, real change is improbable and there is little hope of Japan being able to attract or retain world-class faculty or students. Thus, it involves more than merely those involved with teaching but, to return to Knight's (2008) definition, spans the very purpose and function of the university as a whole, something 
Chapple, J.

not recognized in Japan as yet.

Another missing or flawed component hindering deeper internationalization is what Qiang (2013) refers to as the competency approach. As Yonezawa (2014, p. 50) explains: "Japanese universities and higher education institutions do not assure the knowledge, skills, and competencies that are universally viable in the global labor market, especially those in the English-speaking world." As Yonezawa continues, even the majority of graduates at one of the most 'international' liberal arts colleges in Japan, Akita International University (which offers nearly all its programs in English) seek employment opportunities through the traditional Japanese style employment process. Similarly, the majority of international students in Japan are still studying in Japanese and hoping to find employment related to Japan, either at home or in Japan. What this shows is that systems in Japan have not adjusted to meet the needs or demands of the globalizing world today and until pre- and post- university systems change to suit, there is little pressure or possibility of universities fully internationalizing. "To educate students solely from a domestic point of view means depriving them of a competitive advantage for this interconnected world" (Schroevers, 2011, p. 22).

Finally, returning to the topic of language, one other important issue that is missing is that of what to do with the Japanese language. The teaching of Japanese has reached crisis levels throughout the nation's language schools and university departments. One reason for this may be, as Burgess, et al. (2010) point out, that compulsory Japanese language and culture courses are no longer popular among (particularly) Asian students in Japan (who constitute the majority of international students in the past and in the present G30 project). However, a drop in interest alone is not the only reason. Universities, especially those involved in the G30, are intent on separating Japanese and English as means of instruction.

The segregation of degree courses offered in English from the rest of the curricula in the elite universities seems to be justified by the fact that these courses are offered to foreigners (mainly Asian nationals) without Japanese language skills... In other words, from the beginning, it has not been expected that multicultural nationals will bring ideas and cultures that will contribute to the intellectual environment at Japanese universities, using English as a common language. (Hashimoto, 2013, pp. 29-30)

In other words, this differentiation clearly indicates "programs offered in English do not constitute part of the normal university curricula, but are aimed at bringing 'Others' from overseas to educate them as 'Others' in a carefully tailored but isolated environment” (Hashimoto, 2013, p. 30). Once again projecting a façade and keeping internationalization at arm's length by such disparate language policies is unlikely to have profound meaning for local students.

\section{Conclusion}

The recent proposals explained by Japan's political leaders and education officials aimed at internationalizing higher education are, on face value, prudent, positive and well intentioned. However, as is apparent by the lack of specific plans, details and policy, there is little commitment and likelihood of overwhelming change being effected in the immediate future. This points to the conclusion that internationalization this time again, is more a façade than a feasible possibility.

Japan's 'people plans,' such as seeking an increase in the number of foreign faculty, international students in Japan or Japanese students studying abroad, are all key components in an internationalization equation. However, other than numerical targets, little else exists. There is little to show either for the full and unequivocal acceptance of such persons yet. It is essential for institutions and departments to create a climate of inclusivity that recognizes the academic advantages and contributions of international faculty and students in all functions of their work and not just in research (Mamiseishvili \& Rosser, 2009). This, in turn, requires society itself to acknowledge and adjust to create an atmosphere conducive and compelling for internationalization to occur. At present there is little evidence of this happening in Japan. 
Finally feasible or fresh façade? Analyzing the internationalization plans of Japanese universities

The other significant push is towards teaching more and more classes in English. However, without focusing more on content and delivery style, Japan is either falling into the trap of believing the misconceptions of internationalization as facts (de Wit, 2011) or purposefully using the notion to its advantage. Present facts tend to imply it is most likely the latter. The dual-focused CLIL approach to teaching is almost non-existent. The most common EMI approach would suffice if accompanied by appropriate and targeted support structures but appears to be simplistically viewed as a panacea for instigating internationalization. Regardless, an emphasis on EMI, either real or inferred, certainly has the potential to create a wash-back effect on Japan's high schools, and even elementary schools (Ferguson, 2006; Tsui, 2004) but presently there is even no evidence of this happening.

Finally, in terms of curriculum content, what is required is the implementation of "pedagogical strategies that foster intercultural understanding and world-mindedness" (Worthman, 2013, p. 26), or what Qiang (2013) means by an ethos approach, as well as visible changes to open it to greater scrutiny and equitable evaluation. Almost no moves have been witnessed in this direction, either. Japan is fighting hard to appeal to the goals of internationalization while at the same time ensuring that comprehensive and deep change remains restricted. This is perhaps the greatest of all academic calisthenics, yet sadly the least likely to assist higher education in Japan to remain competitive.

\section{References:}

Altbach, P. G. (2005). Globalization and the university: myths and realities in an unequal world. In H. Wechsler (Ed.), The NEA 2005 Almanac of Higher Education (pp. 63-74). Washington, DC: NEA.

Altbach, P. G. (2006). The internationalization of higher education: motivations and realities. In H. Wechsler (Ed.), The NEA 2006 Almanac of Higher Education (pp. 27-36). Washington, DC: NEA.

Askew, D. (2011). The Japanese university and internationalisation: The global 30 project, foreign students and institutional survival. Asia Pacific World, 21(1), 95-120. http://dx.doi.org/10.3167/apw.2011020106

Barnard, R. (2013, October 30-31). English medium instruction in Asian universities: some concerns and a suggested approach to dual-medium instruction. Paper presented at the 6th CONAPLIN: International Conference on Applied Linguistics: Shaping and Reshaping Linguistic Identity, Indonesian University of Education, Indonesia.

Brady, A. (2008). Developing a civic educational vision and practice for foreign-additional-other (FAO) language and content integration in higher education. In R. Wilkinson \& V. Zegers (Eds.), Realizing content and language education in higher education (pp. 96-109). Maastricht, Netherlands: Maastricht University Language Centre.

Brandenburg, U., \& de Wit, H. (2010). The end of internationalisation. EAIE Forum (Winter), 30-31, 33.

Brock-Utne, B. (2013). Language: everybody's talking (about) it. EAIE Forum (Winter), 16-18.

Burgess, C., Gibson, I., Klaphake, J., \& Selzer, M. (2010). The 'Global 30’ project and Japanese higher education reform: an example of 'closing in' or an 'opening up'? Globalisation, Societies and Education, 8(4), 461-475. http://dx.doi.org/10.1080/14767724.2010.537931

Cantwell, B., \& Maldonado-Maldonado, A. (2009) Four stories: Confronting contemporary ideas about globalisation and internationalisation in higher education. Globalisation, Societies and Education, 7(3), 289-306. http://dx.doi.org/10.1080/14767720903166103

Cason, J., \& Rodriguez, P. (2013). Why English? EAIE Forum (Winter), 14-15.

Chapple, J. (2013). "Global jinzai," Japanese higher education and the path to multiculturalism: Imperative, imposter or immature? (Afrasia Working Paper 25). Otsu, Shiga: Afrasia Research Centre. Retrieved March 12, 2014, from http://afrasia.ryukoku.ac.jp/english/publication/upfile/WP25.pdf

Chin, L. M. C., Wu, C. T., \& Ching, G. S. (2012). Apple and oranges: Comparison of Taiwan higher education institutions' internationalization. International Journal of Research Studies in Education, 1(2), 3-22. http://dx.doi.org/10.5861/ijrse.2012.v1i2.24

de Wit, H. (2002). Internationalization of higher education in the United States of America and Europe: a historical, comparative, and conceptual analysis. Westport, CT: Greenwood Publishers. 
Chapple, J.

de Wit, H. (2011). Misconceptions on internationalization of higher education. Retrieved April 3, 2014, from http://www.eurashe.eu/wp-content/uploads/2011/10/intlztion-Misconceptions.pdf

Echevarria, J.A., \& Graves, A. (2006). Sheltered content instruction: Teaching English language learners with diverse abilities (3rd ed.). Boston, MA: Allyn \& Bacon.

Ferguson, G. (2006). Language planning and education. Edinburgh, Scotland: Edinburgh university press.

Fujita, I. \& Griek, L. (2011). Japanese Higher Education: Recent developments and challenges of globalization. EAIE Forum (Winter), 18-20.

Gappa, J. M., Austin, A. E., \& Trice, A. G. (2007). Rethinking faculty work: Higher education's strategic imperative. San Francisco, CA: Jossey-Bass.

Gibbons, P. (2002). Scaffolding language, scaffolding learning: Teaching second language learners in the mainstream classroom. London: Heinemann.

Goodman, R. (2010). The rapid redrawing of boundaries in Japanese higher education. Japan Forum, 22(1-2), 65-87. http://dx.doi.org/10.1080/09555803.2010.488944

Hashimoto, K. (2000). 'Internationalisation is' 'Japanisation': Japan's foreign language education and national identity. Journal of Intercultural Studies, 21(1), 39-51. http://dx.doi.org/10.1080/07256860050000786

Hashimoto, K. (2013). 'English-only', but not a medium-of-instruction policy: the Japanese way of internationalising education for both domestic and overseas students. Current Issues in Language Planning, 14(1), 16-33. http://dx.doi.org/10.1080/14664208.2013.789956

Hawawini, G. (2011). The internationalization of higher education institutions: A critical review and a radical proposal. Faculty and Research Working Paper. Retrieved March 8, 2014, from http://www.insead.edu/facultyresearch/research/doc.cfm?did=48726

Holifena, J. (n.d.). Mixed reaction to Japan's 'English-only' junior high school classes. Retrieved March 12, 2014, from http://japandailypress.com/mixed-reaction-to-japans-english-only-junior-high-school-classes-1640983/

ICEF Monitor. (2013). Study finds more European universities offering graduate programmes in English. Retrieved February 18, 2014, from http://monitor.icef.com/2013/10/study-finds-more-european-universities-offering-graduate-programmes -in-english/

Igami, K. (2014). Reform of university education for non-elite university students. Japan Labor Review 11(2), 53-68.

Iiyoshi, H. (2008). Request from industry on university education in post-war Japan (sengo nihon sangyokai no daigaku kyoiku yokyu). Tokyo: Toshindo.

Iwabuchi, K. (2005). Multinationalizing the multicultural: Commodification of 'ordinary residents' in a Japanese TV talk show. Japanese Studies: Bulletin of the Japanese Studies Association of Australia, 25(2), 103-118. http://dx.doi.org/10.1080/10371390500225987

Japan Society for the Promotion of Science. (n.d.). Project for establishing university network for internationalization (Global 30). Retrieved 10 April, 2014, from http://www.jsps.go.jp/english/e-kokusaika/.

JASSO. (2013). Survey pertaining to the number of foreign exchange students in Japan 2012 (Heisei 24nendo gaikokujin ryugakusei zaiseki jyokyo chosa ni tsuite). Retrieved 12 March, 2014, from http://www.jasso.go.jp/statistics/intl_student/documents/gaikyo12.pdf

Kariya, T. (2014). Japanese university reforms and the illusion of international competitiveness. Retrieved 12 March, 2014, from http://www.nippon.com/en/in-depth/a02803/

Kitamura, K. (1987). Internationalization of university education (Daigaku no kokusaika). Tokyo: Tamagawa University Press.

Knight, J. (2008). Higher Education in Turmoil: The changing world of internationalisation. Rotterdam: Sense Publishers.

Kubota, R. (2002). The impact of globalization on language teaching in Japan. In D. Block \& D. Cameron (Eds.), Globalization and language teaching (pp. 13-28). London: Routledge.

Lassegard, J. (2013). Student perspectives on international education: an examination into the decline of 
Finally feasible or fresh façade? Analyzing the internationalization plans of Japanese universities

Japanese studying abroad. Asia Pacific Journal of Education, 33(4), 365-379. http://dx.doi.org/10.1080/02188791.2013.807774

Lincicome, M. (2005). Globalization, education, and the politics of identity in the Asia-Pacific. Critical Asian Studies, 37(2), 179-208. http://dx.doi.org/10.1080/14672710500106242

Mamiseishvili, K., \& Rosser, V. (2009). International and citizen faculty in the United States: An examination of their productivity at research universities. Research in Higher Education, 51, 88-107. http://dx.doi.org/10.1007/s11162-009-9145-8

Mannari, H., \& Befu, H. (1985). The challenge of Japan's internationalization: Organization and culture. Tokyo: Kodansha.

Marsh, D., Mehisto, P., Wolff, D., \& Frigols Martin, M. J. (n.d.). European framework for CLTL teacher education. Frankfurt am Main, Germany: Council of Europe. Retrieved 13 March, 2014, from http://clil-cd.ecml.at/EuropeanFrameworkforCLILTeacherEducation/tabid/2254/language/en-GB/Defaul $\underline{\text { t.aspx }}$

Maruyama, H. (2011). International student policy in Japan. Retrieved 10 March, 2014, from http://www.nier.go.jp/English/EducationInJapan/Education_in_Japan/Education_in_Japan_files/201203 IntlSt.pdf

McKenzie, R. M. (2014). Speech evaluation intergroup relations and the Internationalisation of Japanese Higher Education [PowerPoint slides]. Retrieved 1 March, 2014, from www.ncl.ac.uk/ecls/.../McKenzie_Newcastle_Jan_14.ppt

MEXT. (2013). Proposals and cabinet discussion items concerning the globalization of universities (Daigaku no gurobaruka ni kansuru kakugi kettei, teigen). Retrieved 13 March, 2014, from http://www.mext.go.jp/b_menu/shingi/chukyo/chukyo4/036/siryo/attach/1344786.htm

Ministry of Finance. (2013). Highlights of the budget for FY2014. Ministry of Finance. Retrieved 1 March, 2014, from http://www.mof.go.jp/english/budget/budget/fy2014/01.pdf

Mohan, B. (2001). The second language as a medium of learning. In C. Leung, B. Mohan, \& C. Davison (Eds.), English as a second language in the mainstream: Teaching, learning and identity (pp. 107-26). Harlow: Pearson.

Nakayama, S. (1989). Independence and choice: Western impacts on Japanese higher education. In Ph. G. Altbach \& V. Selvaratnam (Eds.), From dependence to autonomy (pp. 97-114). Dorcrecht: Kluwer Academic Publishers.

Phillipson, R. (2009). Linguistic imperialism continued. London: Routledge.

Qiang, Z. (2003). Internationalization of higher education: Towards a conceptual framework. Policy Futures in Education, 1(2), 248-270. http://dx.doi.org/10.2304/pfie.2003.1.2.5

Rappleye, J. (2013, December 13). Higher-education stimulus would be sure bet for Japan. The Japan Times, p. 13.

Salmi, J. (2009). The challenge of establishing world-class universities. The World Bank. Retrieved 24 February, 2014, from

http://web.worldbank.org/WBSITE/EXTERNAL/TOPICS/EXTEDUCATION/0,,contentMDK:2210363

7 menuPK:617592 pagePK:148956 piPK:216618 theSitePK:282386,00.html

Sawa, T. (2013, June 24). Commentary: Top students shunning Japan. The Japan Times, p. 17.

Schroevers, S. (2011). Internationalisation at home E-projects. EAIE Forum (Winter), 21-23.

Selzer, M., \& Gibson, I. (2009). Preparing Japanese students for English-medium instruction in international studies: Methodology and practice in the IIIS international public service program. Ritsumeikan Journal of International Studies, 22(1), 127-40.

Shimizu, K. (2000). Japanese college students' attitudes towards teachers: A survey. Retrieved 1 March, 2014, from http://jalt-publications.org/old_tlt/files/95/oct/shimizu.html

Smith, A. (1994). Quality and international higher education. EAIE Newsletter, no. 13. (Amsterdam: EAIE).

Spring, J. (2009). Globalization of education. New York, NY: Routledge.

Stearns, P. (2008). Educating global citizens in colleges and universities: Challenges and opportunities. New York, NY: Routledge. 
Chapple, J.

Symon, M., \& Weinberg, L. (2013). Teaching in English: perceptions from Israel. EAIE Forum (Winter), 22-24.

The number of students studying abroad falls for the $6^{\text {th }}$ consecutive year [Kaigai ryugaku 6nen renzoku gen].

(2013, February 9). Nihon Keizai Shimbun, p. 13.

Tsui, A. (2004). Medium of instruction in Hong Kong: One country, two systems, whose language? In J.

Tollefson \& A. Tsui (Eds.), Medium of instruction policies: Which agenda, Whose agenda? (pp. 97-116), Mahwah, NJ: Lawrence Erlbaum.

Two barriers to internationalisation [Kokusaika ni futatsu no kabe]. (2013, September 30). Nihon Keizai Shimbun, p. 27.

Universities, finding a way to produce international people [Daigaku, kokusaijin ikusei ni katsuro]. (2013, September 29). Nihon Keizai Shimbun, p. 1.

Vihman, V. (2013). Language: Everybody's talking (about) it. EAIE Forum (Winter), 8-9.

Wildavsky, B. (2010). The great brain race: How global university are reshaping the world. Princeton University Press.

Worthman, C. (2013). Teaching the teachers. EAIE Forum (Winter), 25-27.

Yonezawa, A. (2010). Much ado about ranking: Why can't Japanese universities internationalize? Japan Forum, 22(1), 121-137. http://dx.doi.org/10.1080/09555803.2010.488948

Yonezawa, A. (2014). Japan's challenge of fostering "global human resources": Policy debates and practices. Japan Labor Review, 11(2), 37-52.

Yonezawa, A., Abe, H., \& Hirouchi, D. (2009). Japanese university leaders' perceptions of internationalization: The role of government in review and support. Journal of Studies in International Education, 13(2), 125-142. http://dx.doi.org/10.1177/1028315308330847 